\title{
Plankton studies in Buzzards Bay, Massachusetts, USA. II. Nutrients, chlorophyll $a$ and phaeopigments, 1987 to 1990
}

\author{
David G. Borkman*, Jefferson T. Turner** \\ Center for Marine Science and Technology, University of Massachusetts, Dartmouth, North Dartmouth, Massachusetts 02747, USA
}

\begin{abstract}
As part of a larger study of hydrography, water chemistry and plankton in Buzzards Bay, Massachusetts, USA, we quantified levels of nutrients (ammonium, nitrate, nitrite, orthophosphate, silicate), chlorophyll $a$ and phaeopigments from 1 October 1987 to 11 September 1990 ( $\mathrm{n}=1080$ for each parameter). Although there were considerable monthly, seasonal and interannual fluctuations of some variables, certain trends were apparent. Ammonium comprised up to $99.79 \%$ (mean $=75.79 \%$ ) of total dissolved inorganic nitrogen ( $\mathrm{DIN}=\mathrm{NH}_{4}{ }^{+}+\mathrm{NO}_{3}{ }^{-}+\mathrm{NO}_{2}{ }^{-}$). This was due to nutrient loading at one station from a sewage outfall, and to resuspension of benthic nutrients due to shallow depth and frequent mixing throughout the entire bay. Nitrate levels were maximal in winter, whereas those of orthophosphate were higher during the warmer months. Both variables exhibited interannual variation. Silicate exhibited sustained bay-wide summer increases in all 3 years, followed by precipitous declines in autumn. Inverse relationships between silicate and diatoms during 1987 to 1988 suggest that silicate fluctuations were biologically related, in that the summer increase was a rebound from heavy utilization during the spring diatom bloom, and the autumn silicate decline was due to utilization by a fall diatom bloom. Chlorophyll a levels were comparatively high (>5.0 $\mathrm{mg} \mathrm{l}^{-1}$ ) and relatively uniform throughout the bay except for higher concentrations near the sewage outfall, or within an enclosed harbor where a hurricane dike appears to increase residence times of phytoplankton blooms by reducing circulation. Buzzards Bay is a habitat favorable to high phytoplankton production because shallow depth and frequent mixing result in a water column that is holomictic and euphotic throughout most of the year, and the sediments act as a nutrient pump injecting ammonium and other remineralized nutrients into the water column.
\end{abstract}

\section{INTRODUCTION}

Nutrient loading and eutrophication of coastal marine waters is increasingly becoming a problem at many locations around the globe. Anthropogenic nutrient enrichment from sewage disposal or agricultural runoff can stimulate overproduction of phytoplankton biomass, which upon decomposition can cause reduced water quality or anoxia. Also, nutrient enrichment may be linked to a possible epidemic of toxic or noxious phytoplankton blooms (Smayda 1990).

\footnotetext{
- Present address: Graduate School of Oceanography, University of Rhode Island, Narragansett, Rhode Island 02882, USA

- Addressee for reprint requests
}

Like other urbanized estuaries, Buzzards Bay (Massachusetts, USA) has portions that are becomming increasingly eutrophic. A conspicuous area is New Bedford Harbor, where the city's sewage outfall discharges $>90000 \mathrm{~m}^{3} \mathrm{~d}^{-1}$ of poorly treated effluent that is nominally primary treated, but in actuality appears and smells to be virtually raw. However, the bay is large $\left(590 \mathrm{~km}^{2}\right)$, and many areas receive little anthropogenic discharge or natural runoff. Also, due to shallow depths $(<20 \mathrm{~m})$ and dynamic wind and tidal mixing, resuspension of bottom sediments frequently injects regenerated nutrients from the benthos back into the water column (Rhoads et al. 1975, Roman 1978). Thus, the nutrient regime of Buzzards Bay is complicated, and it is important to clarify temporal and spatial patterns throughout the estuary. 
Since 1987 we have maintained monthly or biweekly sampling of hydrography, chemistry and plankton in Buzzards Bay. The overall rationale and introduction for the study, together with descriptions of stations and sampling protocol, are presented in Turner \& Borkman (1993; companion article). We here present results on nutrients, chlorophyll $a$ and phaeopigments for the first 3 years of the study (October 1987 to September 1990 ).

\section{METHODS}

Nutrients. At surface, mid-depth and bottom depths at all stations on all cruises, concentrations of ammonium, nitrate, nitrite, orthophosphate and silicate were measured ( $n=1080$ samples for each nutrient). To avoid measuring levels of nutrients in plankton or other particulates in addition to dissolved nutrients, all samples were prefiltered aboard ship through Whatman GFC glass fiber filters. Blanks on unfiltered water were performed to correct for any silicon additions from the filters. Samples were refrigerated, but not frozen, until return to the laboratory $k 1 \mathrm{~h}$ after docking), and ammonium analyses were performed the night after each cruise on unfrozen samples. In most cases nitrate and nitrite samples were analyzed similarly, but in a few cases analyses were performed on frozen samples the day after a cruise. Phosphate and silicate samples were frozen and analyzed within 2 to $3 \mathrm{~d}$ of collection.

Analyses were performed with either a Technicon Autoanalyzer 2 (Cruises 1 to 17) or an Alpkem RFA-300 Elemental Analyzer (Cruises 16 to 45). An intercalibration of both instruments on all samples from Cruises 16 \& 17 revealed comparable data. The chemistry for analyses with both instruments was essentially that of Parsons et al. (1984).

Chlorophyll $a$ and phaeopigments. Samples from surface, mid-depth and bottom depths at all stations on all cruises $(n=1080)$ were filtered aboard ship through Whatman GFC glass fiber filters. Either $100 \mathrm{ml}$ or usually $200 \mathrm{ml}$ was filtered, and filters were coated immediately with $1 \% \mathrm{MgCO}_{3}$ to prevent pigment degradation. Filters were individually wrapped in aluminum foil and kept on ice until return to the laboratory. Either the night after each cruise, or the next day (after freezing overnight), filters were disintegrated in $90 \%$ acetone and kept for an additional day in a freezer in the dark for maximum extraction of pigments. Chlorophyll a and phaeopigment analyses were done with a Turner Designs Model 10 fluorometer according to the methodology of Parsons et al. (1984). Phaeopigment analyses were done after acidification with 2 drops of $1 \mathrm{~N} \mathrm{HCl}$.
Phytoplankton. Although detailed data on phytoplankton species composition and abundance will be presented elsewhere, since we present some of these data here, a brief description of methodology is appropriate.

Samples of $800 \mathrm{ml}$ each were taken from surface, mid-depth and bottom Niskin bottle collections and preserved in Utermöhl's solution (Guillard 1973). Cells were concentrated by gravimetric sedimentation (ashore) in graduated cylinders until aliquots of $10 \mathrm{ml}$ were obtained. These aliquots were examined in Sedgwick-Rafter counting chambers, and all cells were counted and identified to the lowest possible taxon. In most cases, aliquots of at least 400 cells were counted, giving accuracy of $\pm 10 \%$ or better (Guillard 1973). Use of an Olympus BH-2 phase-contrast microscope equipped with long-working-distance objectives $<4 \mathrm{~cm}$ in length allowed use of the Sedgwick-Rafter cells at $400 x$

\section{RESULTS}

\section{Nutrients}

Nutrient values over all depths are presented in Table 1. Due to the shallow holomictic water column, nutrient levels at all stations except Stn 7 were virtually homogeneous with depth. Thus, plots of areal and temporal distributions (see Figs. 1 to 5) present surface data only. However, due to the surface plume of effluent from the New Bedford sewage outfall, levels of ammonium and orthophosphate at the surface at Stn 7 were usually higher than at other depths at the same station, or at any depth in the rest of the bay (Table 2). This was not the case for distributions of nitrate and silicate (Table 2). Such a pattern would be expected in an area impacted by sewage effluent,

Table 1. Ranges, means and standard deviations of concentrations of nutrients and phytoplankton pigments from surface, mid-depth, and bottom samples $(n=1080)$ in Buzzards Bay (Cruises 1 to 45), October 1987 to September 1990

DIN: dissolved inorganic nitrogen $=\mathrm{NH}_{4}{ }^{+}+\mathrm{NO}_{3}{ }^{-}+\mathrm{NO}_{2}^{-}$

\begin{tabular}{|lcrr|}
\hline & Range & Mean & $\pm \mathrm{SD}$ \\
\hline Ammonium $(\mu \mathrm{M})$ & $0.00-70.52$ & 3.46 & 4.65 \\
Nitrate $(\mu \mathrm{M})$ & $0.00-5.76$ & 0.75 & 0.93 \\
Nitrite $(\mu \mathrm{M})$ & $0.00-1.16$ & 0.22 & 0.25 \\
$\%$ of total DIN & $0.00-99.79$ & 75.79 & 16.23 \\
$\quad$ as ammonium & $0.10-7.12$ & 0.84 & 0.76 \\
Orthophosphate $(\mu \mathrm{M})$ & $0.19-30.14$ & 5.26 & 4.79 \\
Silicate $(\mu \mathrm{M})$ & $1.79-64.66$ & 8.74 & 6.98 \\
Chlorophyll a $\left(\mu \mathrm{g} \mathrm{l}^{-1}\right)$ & 1.13 & 1.37 \\
Phaeopigments $\left(\mu \mathrm{gl} \mathrm{l}^{-1}\right)$ & $0.00-12.25$ & 1.00 & \\
\hline
\end{tabular}


Table 2. Comparison of station means of nutrient concentrations $(\mu \mathrm{M})$ for surface, mid-depth, and bottom samples for Cruises 1 to 45 for $S \operatorname{tn} 7$ (New Bedford sewage outfall) and Stn 8 (New Bedford inner harbor) versus Stns 1 to 6. Each mean represents the 45 discrete nutrient values for a station at a given depth

\begin{tabular}{|llcrc|}
\hline Nutrient & Depth & $\begin{array}{c}\text { Stns 1-6, } \\
\text { range of means }\end{array}$ & $\begin{array}{c}\text { Stn 7, } \\
\text { mean }\end{array}$ & $\begin{array}{r}\text { Stn 8, } \\
\text { mean }\end{array}$ \\
\hline $\mathrm{NH}_{4}{ }^{+}$ & Surface & $2.33-5.39$ & 16.40 & 4.41 \\
& Mid-depth & $1.85-2.65$ & 5.83 & 4.23 \\
& Bottom & $1.75-2.48$ & 2.95 & 4.43 \\
$\mathrm{PO}_{4}{ }^{3-}$ & Surface & $0.47-0.72$ & 3.00 & 1.22 \\
& Mid-depth & $0.53-0.76$ & 1.60 & 1.26 \\
& Bottom & $0.52-0.68$ & 1.01 & 1.32 \\
$\mathrm{SiO}_{3}{ }^{2-}$ & Surface & $3.75-6.68$ & 7.51 & 6.43 \\
& Mid-depth & $3.88-5.40$ & 4.96 & 6.05 \\
& Bottom & $4.09-6.84$ & 5.61 & 6.47 \\
$\mathrm{NO}_{3}{ }^{-}$ & Surface & $0.62-0.91$ & 1.17 & 1.10 \\
& Mid-depth & $0.60-0.81$ & 1.00 & 0.93 \\
& Bottom & $0.59-0.74$ & 0.77 & 0.82 \\
& & & & \\
\hline
\end{tabular}

since ammonium is a degradation product of urea, and high phosphates in sewage reflect detergents (Ryther \& Dunstan 1971). High levels of ammonium and orthophosphate were also found at Stn 8 in the New Bedford inner harbor (Table 2), but levels were generally similar throughout the water column. This probably reflects shallow depth $(8 \mathrm{~m})$, runoff from the Acushnet River which empties into the northern end of the harbor, and prolonged residence times of water retained behind the hurricane dike.

Surface ammonium levels were highest at Stn 7 , with much lower and comparatively uniform levels elsewhere (Fig. 1), and ammonium was the major form of inorganic nitrogen available throughout the bay. As a percentage of total dissolved inorganic nitrogen (DIN $=\mathrm{NH}_{4}^{+}+\mathrm{NO}_{3}^{-}+\mathrm{NO}_{2}^{-}$), ammonium comprised up to $99.79 \%$, with a mean of $75.79 \%$ (Fig. 2), likely reflecting the shallow water column and resuspension of ammonium regenerated in the benthos. Ammonium values were typically higher during the warmer months, particularly at Stn 7 (Fig. 1).

Surface nitrate distributions (Fig. 3) were different from those of ammonium. Nitrate levels were highest in winters of all 3 years, and fluctuations over time were much more bay-wide than those of ammonium, which were heavily biased by the sewage outfall. There were also differences between years, in that the sustained bay-wide increase in nitrate during fall and early winter of 1989, followed by a precipitous decline in mid- to late winter 1990 was much more dramatic than in previous years.

Surface orthophosphate distributions (Fig. 4) showed clear peaks during the warmer months at $\operatorname{Stn} 7$ in all 3 years. Otherwise, orthophosphate levels were comparatively uniform and low $(<0.5 \mu \mathrm{M})$ throughout the rest of the bay. The high orthophosphate levels at Stn 7 are likely a reflection of sewage effluent, in that the mean concentration at this station was $3.0 \mu \mathrm{M}$, over 3 times that for the bay as a whole $(0.84 \mu \mathrm{M}$; Table 1).

There were sustained bay-wide summer increases in silicate levels, followed by precipitous declines in fall, during each of the 3 years (Fig. 5). The regularity of this trend was not matched by any other nutrient, suggesting a unique, possibly biological cause

\section{Chlorophyll a and phaeopigments}

Surface chlorophyll a levels were comparatively high (>5.0 $\mathrm{mg} \mathrm{l}^{-1}$ ) and relatively uniform throughout the bay (Fig. 6) except for high summer concentrations at Stn 7 (sewage outfall) and Stn 8 (inner harbor). Surface phaeopigments showed no clear trends (Fig. 7) other than consistently low levels compared to chlorophyll $a$, and high levels at Stns $7 \& 8$ when levels of chlorophyll $a$ at these stations were also high.

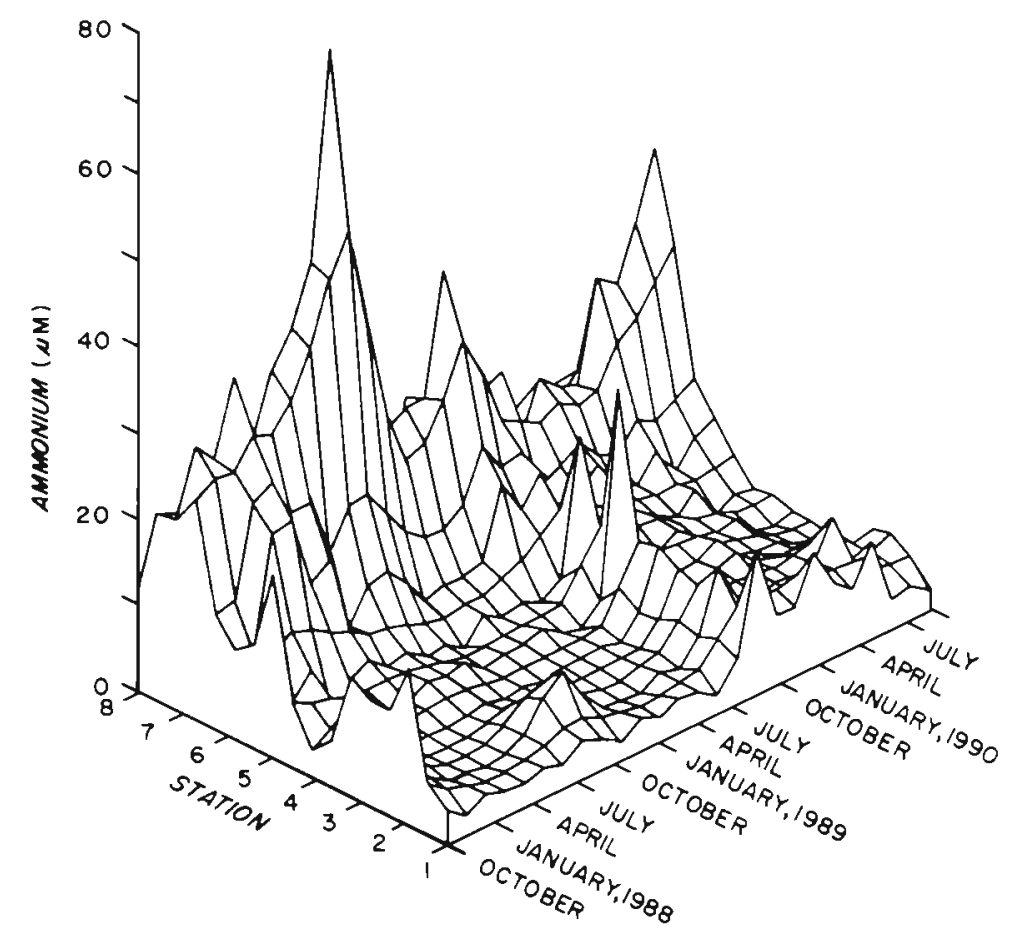

Fig. 1. Surface ammonium $(\mu M), 1$ October 1987 to 11 September $1990(n=360)$ 


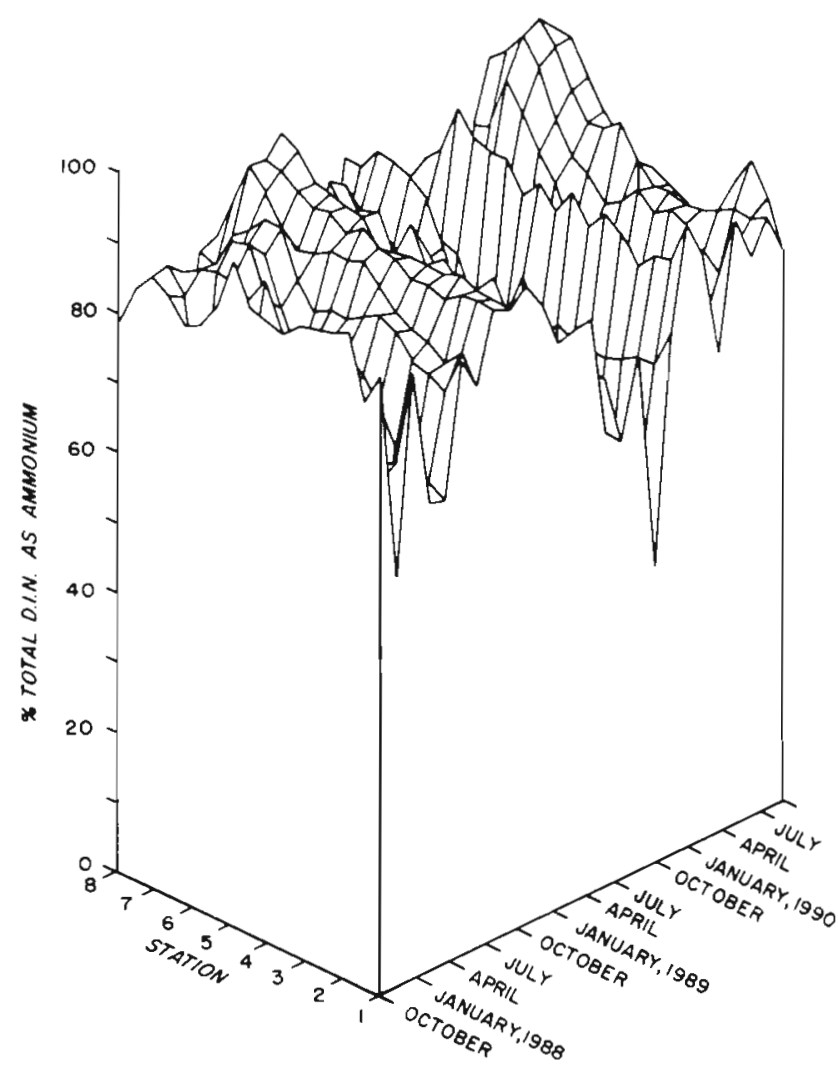

Fig. 2. Percent of total dissolved inorganic nitrogen (DIN) comprised by ammonium, 1 October 1987 to 11 September $1990(\mathrm{n}=360)$

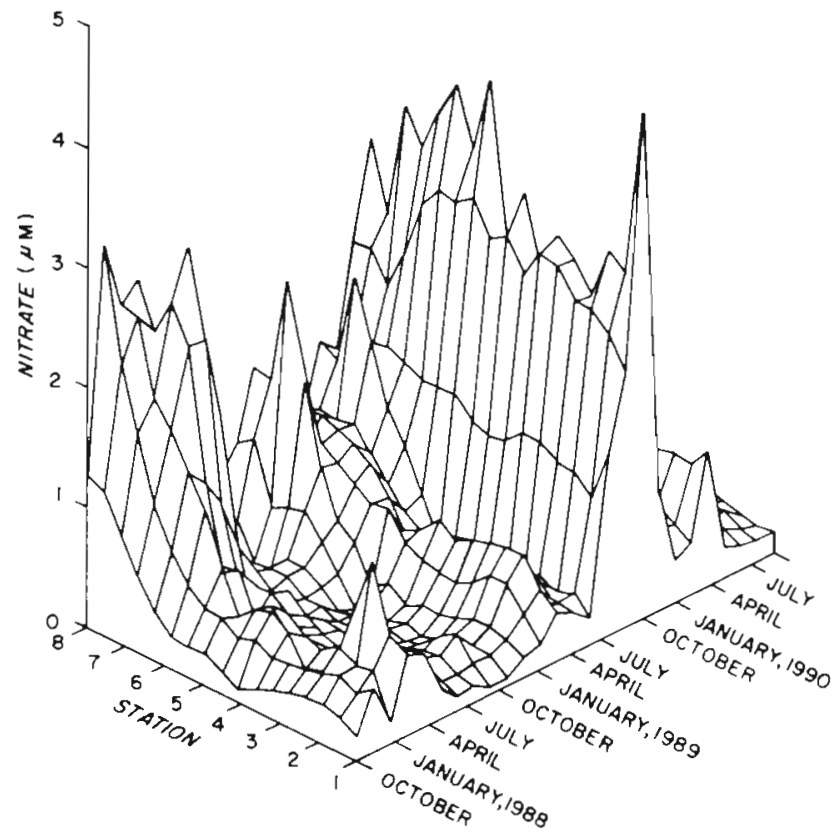

Fig. 3. Surface nitrate $(\mu M), 1$ October 1987 to 11 September $1990(n=360)$

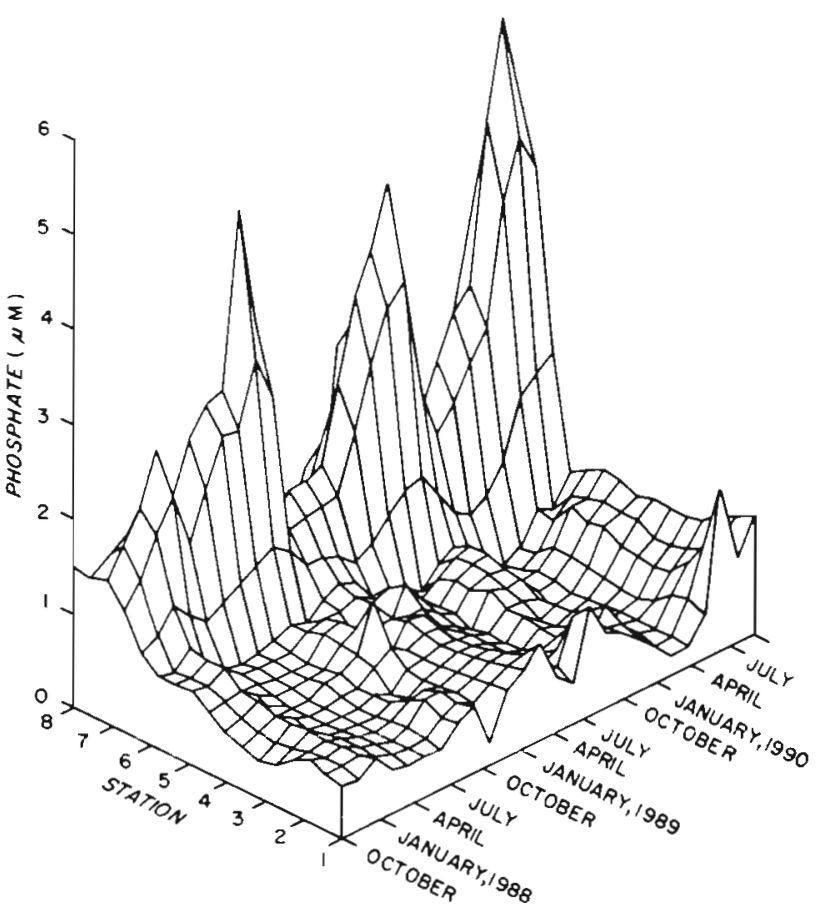

Fig. 4. Surface orthophosphate $(\mu \mathrm{M}), 1$ October 1987 to 11 September $1990(n=360)$

\section{DISCUSSION}

Buzzards Bay is conducive to high phytoplankton production for several reasons. Due to shallow depths, the euphotic zone extends to the bottom for most of the year (Turner \& Borkman 1993). Thus, even though vertical mixing of the water column is frequently complete, shallow depth ensures that critical depth criteria (Sverdrup 1953) are usually met. Mixing also facilitates bottom-up benthic-pelagic coupling. The sediments act as a nutrient pump injecting remineralized inorganics, particularly ammonium, to the water column (Banta et al. 1990). Thus, it is no surprise that ammonium averages $76 \%$ of total DIN throughout the bay (Table 1, Fig. 2). Since nitrogen is usually the primary limiting nutrient in marine systems (Ryther \& Dunstan 1971), the replete nitrogen conditions coupled with adequate light allow abundant phytoplankton growth throughout the year. In this respect, Buzzards Bay is similar to other nearby shallow well-mixed estuaries such as Narragansett (Smayda 1983, 1984) and Peconic Bays (Turner et al. 1983), but unlike deeper summerstratified coastal systems such as Long Island Sound (Conover 1956), Massachusetts and Cape Cod Bays (Townsend et al. 1991), and Georges Bank (Riley 1941) (Table 3).

Buzzards Bay exhibits large seasonal and interannual variations in levels of certain parameters. 


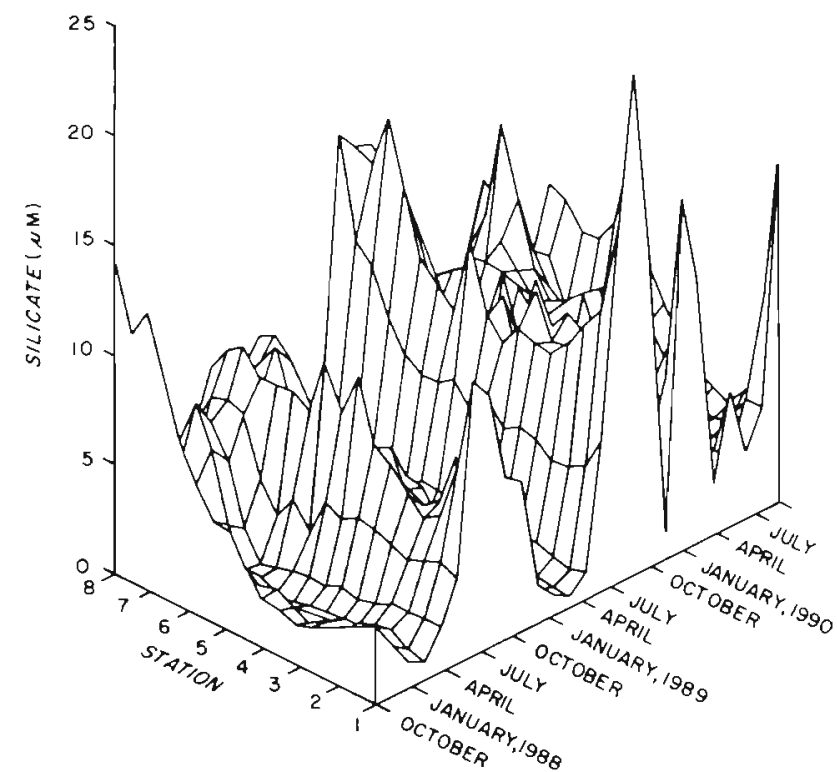

Fig. 5. Surface silicate $(\mu M), 1$ October 1987 to 11 September $1990(n=360)$

These were particularly apparent for nitrate (Fig. 3), silicate (Fig. 5) and phaeopigments (Fig. 7). Other parameters showed more uniform distributions, with the exception of the 2 stations in New Bedford Harbor. Orthophosphate (Fig. 4) and chlorophyll a (Fig, 6) concentrations were generally similar bay-wide on a given day, and over seasons and years for Stns 1 to 6 . However, the signals for elevated concentrations of ammonium (Fig. 1), orthophosphate (Fig. 4), chloro-

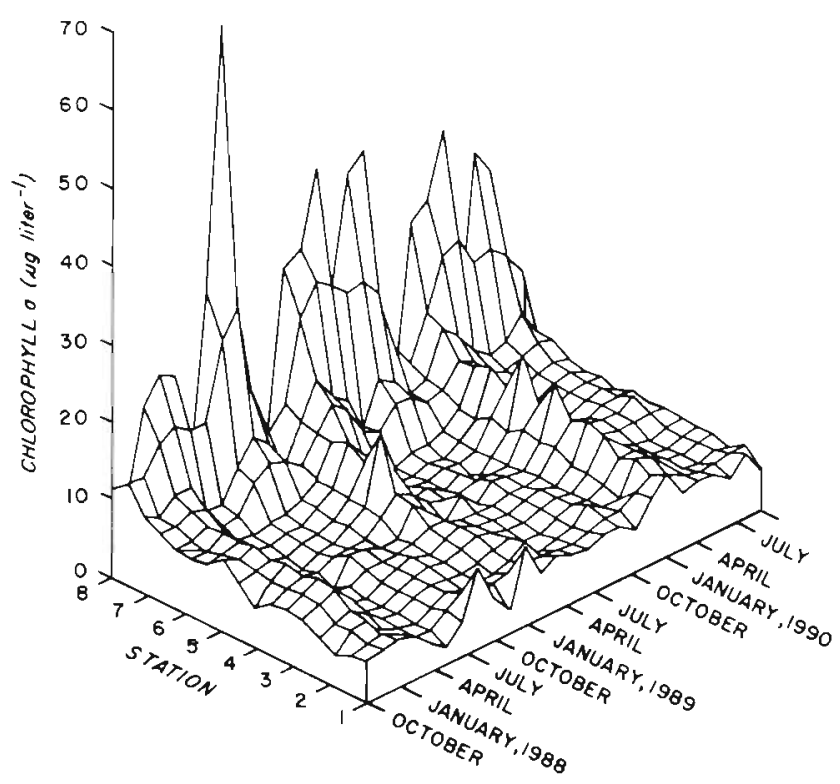

Fig. 6. Surface chlorophyll a $\left(\mu \mathrm{g} \mathrm{l}^{-1}\right), 1$ October 1987 to 11 September $1990(n=360)$

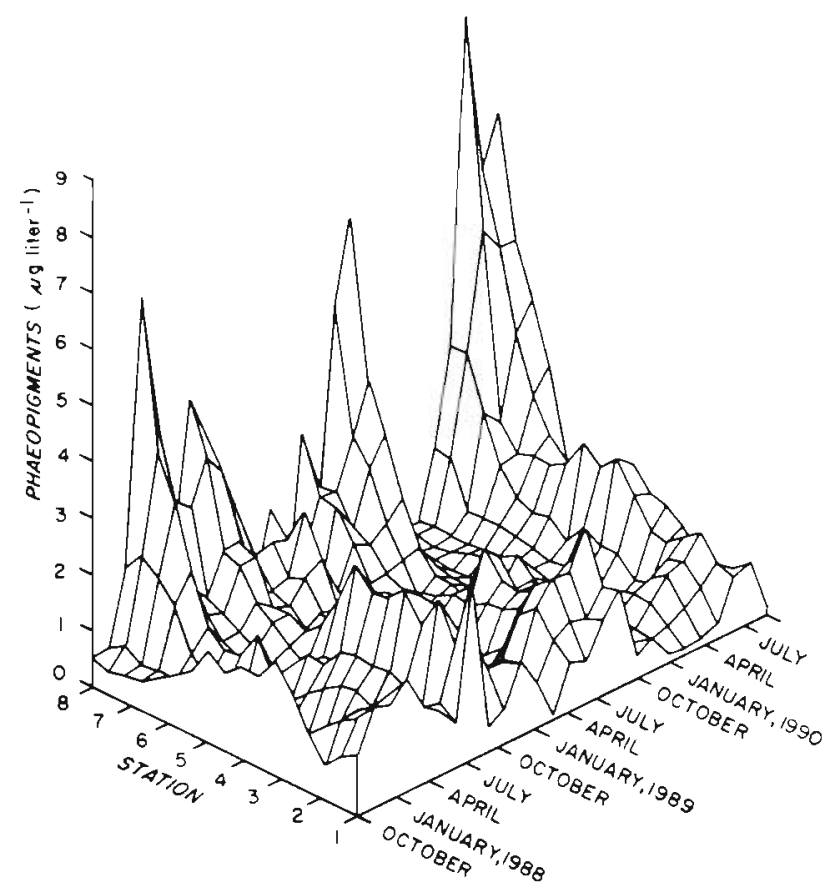

Fig. 7. Surface phaeopigments $\left(\mu \mathrm{g} \mathrm{l}^{-1}\right), 1$ October 1987 to 11 September $1990(\mathrm{n}=360)$

phyll a (Fig. 6), and phaeopigments (Fig. 7) at Stn 7, the sewage outfall, were apparent. High concentrations of these parameters would be expected to reflect sewage effluent, and these data clearly identify the New Bedford sewage outfall as the major eutrophication insult to Buzzards Bay.

Even though nutrient levels were usually lower in the New Bedford inner harbor than at the sewage outfall, chlorophyll a levels at Stn 8 were generally the highest of any of our stations (Fig. 6). We suspect that the reason for this is physical. The hurricane dike across the mouth of the inner harbor almost completely encloses it, creating somewhat of a 'marine lake'. Salinities behind the hurricane dike are typically 1 to $4 \%$ lower than for the rest of the bay, and except for winter, surface temperatures are 1 to $3{ }^{\circ} \mathrm{C}$ higher. Although we are unaware of any substantial study of water exchange between the inner harbor and the rest of the bay, we suspect that circulation is greatly reduced. Thus, phytoplankton and nutrients appear to accumulate in the inner harbor, causing higher chlorophyll a concentrations there. Also, anecdotal evidence supports this suggestion. Green 'blobs' of phytoplankton are frequently collected by zooplankton nets in the inner harbor, when not collected elsewhere on the same day. Cursory examination of such live samples after cruises often reveals that chain-forming diatoms blooming in the inner harbor are not apparent throughout the rest of the bay on the same day, but 
Table 3. Comparison of levels of nutrients and chlorophyll a in Buzzards Bay and adjacent estuarine and coastal waters of the northeastern United States (means italicized, ranges in parentheses)

\begin{tabular}{|c|c|c|c|c|c|c|}
\hline Location and dates & $\begin{array}{c}\text { Chl } a \\
\left(\mu \mathrm{gl}^{-1}\right)\end{array}$ & $\begin{array}{l}\mathrm{NH}_{4}^{+} \\
(\mu \mathrm{M})\end{array}$ & $\begin{array}{l}\mathrm{NO}_{3}^{-} \\
(\mu \mathrm{M})\end{array}$ & $\begin{array}{l}\mathrm{PO}_{4}^{3-} \\
(\mu \mathrm{M})\end{array}$ & $\begin{array}{l}\mathrm{SiO}_{3}{ }^{2-} \\
(\mu \mathrm{M})\end{array}$ & Source \\
\hline $\begin{array}{l}\text { Peconic Bay, New York } \\
\text { (Jun } 1978 \text { to May 1979) }\end{array}$ & $\begin{array}{c}2.94 \\
(1.35-6.59)\end{array}$ & $\begin{array}{c}0.81 \\
(0.05-3.82)\end{array}$ & $\begin{array}{c}0.24 \\
(0.01-1.36)\end{array}$ & $\begin{array}{c}0.66 \\
(0.14-1.62)\end{array}$ & $\begin{array}{c}12.8 \\
(0.5-38.10)\end{array}$ & Turner et al. (1983) \\
\hline $\begin{array}{l}\text { Narragansett Bay } \\
\text { (Oct } 1975 \text { to Mar 1977) }\end{array}$ & $\begin{array}{c}10.26 \\
(1.5-31.7)\end{array}$ & $\begin{array}{c}5.41 \\
(1.1-14.9)\end{array}$ & $\begin{array}{c}4.76 \\
(0.60-12.78)\end{array}$ & $\begin{array}{c}1.34 \\
(0.07-2.27)\end{array}$ & $\begin{array}{c}16.61 \\
(0.82-32.45)\end{array}$ & Smayda (1983) \\
\hline $\begin{array}{l}\text { Long Island Sound } \\
\text { (Mar } 1952 \text { to Mar 1954) }\end{array}$ & $1.8-15.4$ & - & $0.08-16.3$ & $0.39-2.50$ & - & Conover (1956) \\
\hline $\begin{array}{l}\text { Georges Bank } \\
\text { (Sep } 1939 \text { to Jun 1940) }\end{array}$ & - & - & $3.72-17.80$ & $0.373-2.077$ & - & Riley (1941) \\
\hline $\begin{array}{l}\text { Massachusetts Bay } \\
\text { (Oct } 1989 \text { to Aug 1990) }\end{array}$ & $\begin{array}{c}3.08 \\
(0.31-13.99)\end{array}$ & $\begin{array}{c}1.35 \\
(0-11.82)\end{array}$ & $\begin{array}{c}5.11 \\
(0-13.86)\end{array}$ & $\begin{array}{c}0.79 \\
(0.07-2.07)\end{array}$ & $\begin{array}{c}6.42 \\
(0.35-16.36)\end{array}$ & Townsend et al. (1991) \\
\hline $\begin{array}{l}\text { Buzzards Bay } \\
\text { (Oct } 1987 \text { to Sept 1990) }\end{array}$ & $\begin{array}{c}8.74 \\
(1.79-64.66)\end{array}$ & $\begin{array}{c}3.46 \\
(0-70.52)\end{array}$ & $\begin{array}{c}0.75 \\
(0-5.76)\end{array}$ & $\begin{array}{c}0.84 \\
(0.10-7.12)\end{array}$ & $\begin{array}{c}5.26 \\
(0.19-30.14)\end{array}$ & Present study \\
\hline
\end{tabular}

sometimes these taxa were present bay-wide the month before. This suggests that blooms persist longer in the inner harbor than elsewhere, again indicating reduced water exchange. Completion of quantitative analyses of phytoplankton species assemblages should help clarify such trends.

The bay-wide patterns for silicate suggest the possibility of biological control of silicate levels due to variations in silicate utilization by phytoplankton. However, comparisons of chlorophyll a and silicate concentrations over 3 yr revealed no clear pattern (Fig. 8). Since diatoms are the dominant phytoplankters utilizing silicate, and summer dominance by non-silicate-utilizing microflagellates and dinoflagel- lates is a common pattern in estuaries of the northeastern United States (Durbin et al. 1975, Smayda 1983, Turner et al. 1983, Karentz \& Smayda 1984), the possibility is raised that summer silicate increases in Buzzards Bay resulted from differential utilization of silicate due to changes in phytoplankton community composition.

Although phytoplankton community analyses are complete for the first year only $(1987-88)$, it is clear that silicate levels plummeted from early to midsummer highs in response to a late summer phytoplankton bloom (Fig. 9). This bloom was largely composed of the diatom Skeletonema costatum (cruise means $=37$ to $80 \%$ of total cells; Cruises 14 to 17 ,

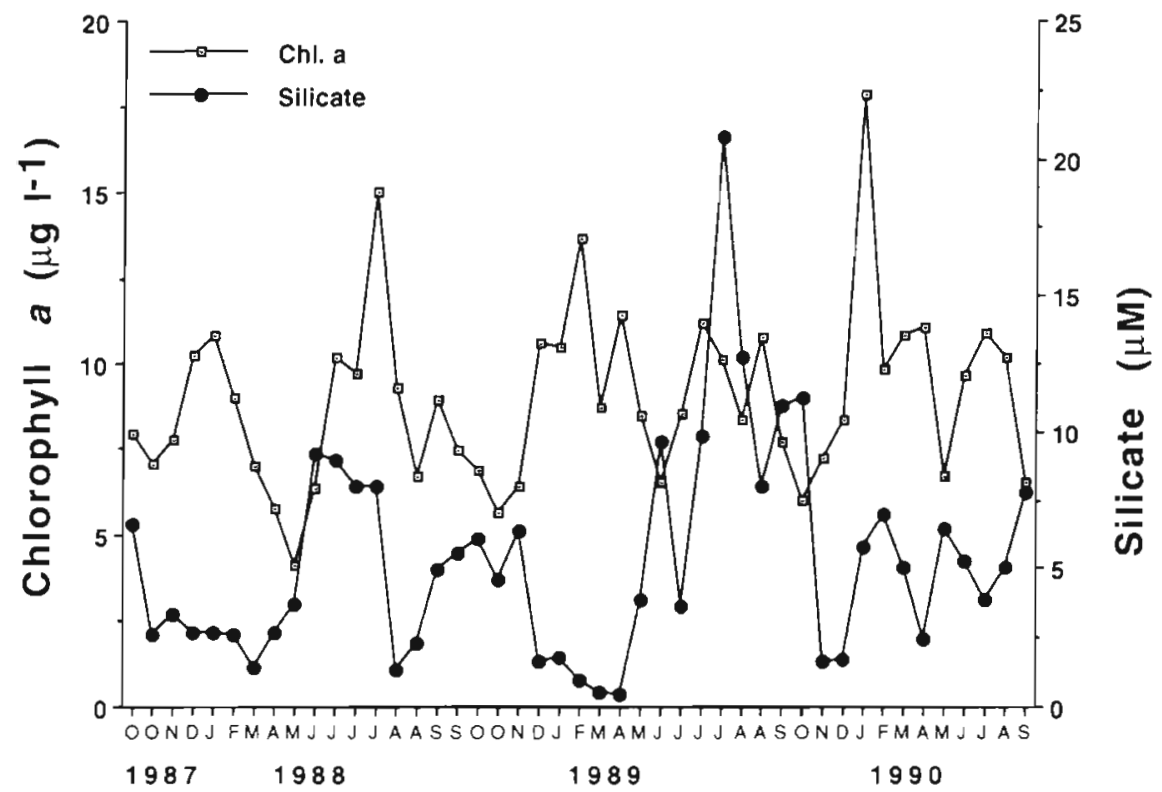

Fig. 8. Silicate $(\mu \mathrm{M})$ vs chlorophyll a $\left(\mu \mathrm{g} \mathrm{l}^{-1}\right), 1$ October 1987 to 11 September 1990. Each value is a baywide mean for all depths for each cruise ( $\mathrm{n}=24$ for each value) 


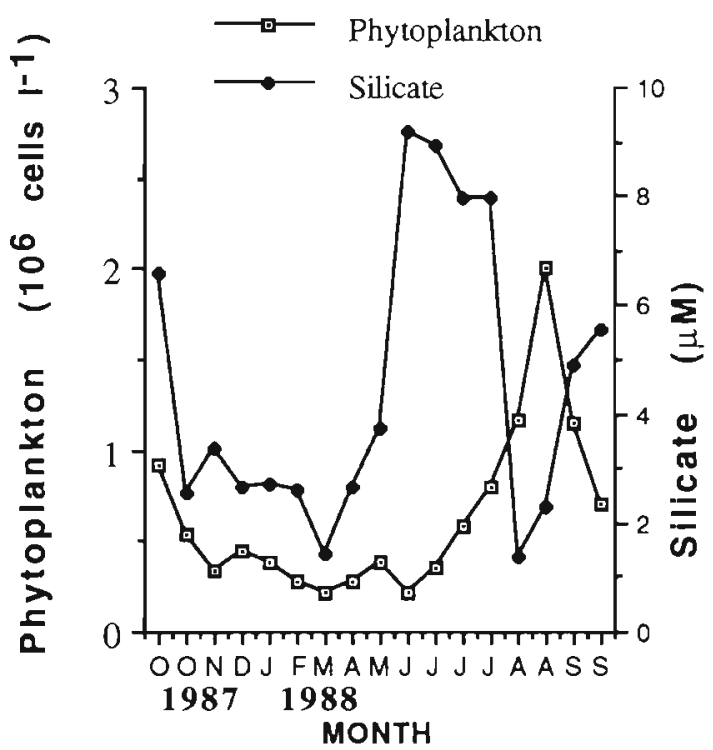

Fig. 9. Silicate $(\mu \mathrm{M})$ vs total phytoplankton (cells $\times 10^{6} 1^{-1}$ ), 1 October 1987 to 20 September 1988. Values are bay-wide means of surface values for each cruise $(n=18$ for each value)

August-September 1988). The other significant period of diatom dominance was during the previous fall and winter, when diatoms of the genus Chaetoceros comprised cruise means of 14 to $60 \%$ of total cells (overall mean $=34 \%$ of total cells; Cruises 1 to 8 , October 1987 to April 1988). Although this earlier period of diatom dominance did not stand out in terms of chlorophyll a (Figs. $6 \& 8$ ) or total phytoplankton cells (Fig. 9), it was glaringly apparent in terms of percentage composition (Fig. 10). Likewise, the August-September 1988 bloom of $S$. costatum was also clearly reflected in the \% diatom composition (Fig. 10). Thus, the May-June 1988 spike in silicate levels coincided with the seasonal zenith in dominance by microflagellates and dinoflagellates, and annual nadir in diatom dominance.

In conclusion, Buzzards Bay appears to be a favorable habitat for phytoplankton in that it is well-mixed and -illuminated, and nutrient-replete. Although there are obvious eutrophication signals from the New Bedford sewage outfall in terms of high ammonium and chlorophyll $a$, and low light penetration, the rest of the estuary appears relatively unimpacted. As with hydrography and bacterioplankton abundance (Turner \& Borkman 1993), nutrients and phytoplankton pigments were highly variable in time and space. While most locations away from New Bedford Harbor exhibited similar values on a given day, the stations at the sewage outfall (Stn 7) and inner harbor (Stn 8) usually had much higher values than the rest of the bay. There were also major fluctuations in nutrients and phytoplankton pigments on time scales ranging from biweekly to monthly to seasonal to interannual. Although much of this fluctuation

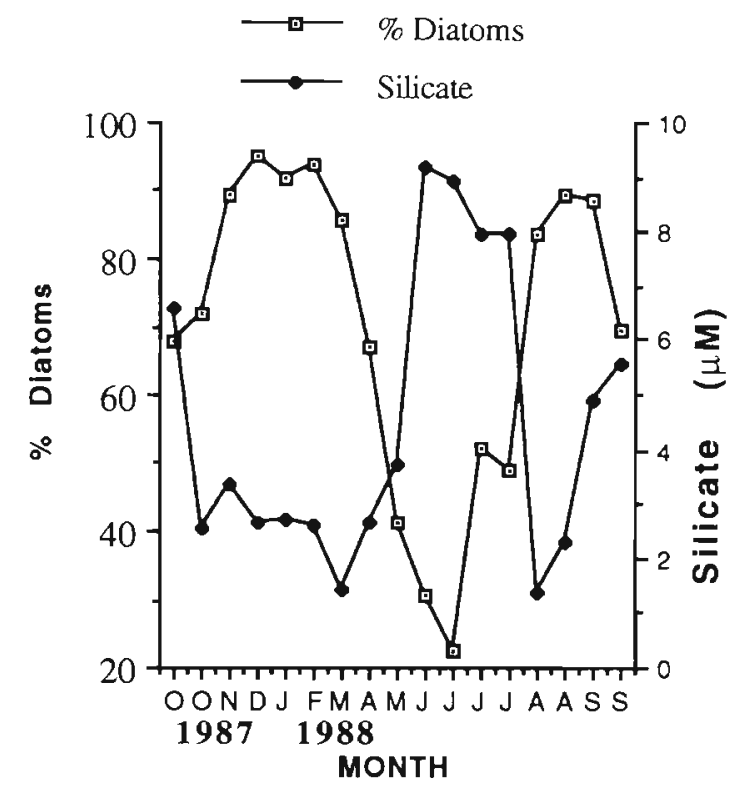

Fig. 10. Silicate $(\mu \mathrm{M})$ vs percentage of total phytoplankton cells comprised by diatoms, 1 October 1987 to 20 September 1988. Values are bay-wide means of surface values for each cruise ( $n=18$ for each value)

appeared due to physical forcing, some such as that of silicate appears to be biologically driven. Consideration of parameter variability in Buzzards Bay is essential for proper understanding and management of this system.

Acknowledgements. In addition to again thanking the Massachusetts Department of Environmental Protection for funding, and other acknowledgements listed in Turner \& Borkman (1993), we thank Z. Mlodzinska (Woods Hole Oceanographic Institution) for performing nutrient analyses from Cruises 1 to 17 , and G. Fain, Director of the Center for Marine Science and Technology, University of Massachusetts, Dartmouth, for funds to purchase reprints.

\section{LITERATURE CITED}

Banta, G. T., Giblin, A. E., Hobbie, J. E., Tucker, J. (1990). Benthic respiration and nitrogen release in Buzzards Bay, Massachusetts. Draft report submitted to the U.S. Environmental Protection Agency, Buzzards Bay Project Grant CX-815451-01-0, 70 p.

Conover, S. A. M. (1956). Oceanography of Long Island Sound, 1952-1954. IV. Phytoplankton. Bull. Bingham Oceanogr. Coll. 15: 62-112

Durbin, E. G., Krawiec, R. W., Smayda, T. J. (1975). Seasonal studies on the relative importance of different size fractions of phytoplankton in Narragansett Bay (USA). Mar. Biol. 32: 271-287

Guillard, R. R. L. (1973). Division rates. In: Stein, J. R. (ed.) Phycological methods. Cambridge University Press, Cambridge, p. 289-311

Karentz, D., Smayda, T. J. (1984). Temperature and seasonal occurrence patterns of 30 dominant phytoplankton 
species in Narragansett Bay over a 22-year period (1959-1980). Mar. Ecol. Prog. Ser. 18: 277-293

Parsons, T R., Maita, Y., Lalli, C. M. (1984). A manual of chemical and biological methods for seawater analysis. Pergamon Press, Oxford

Rhoads, D. C., Tenore, K., Browne, M. (1975). The role of resuspended bottom mud in nutrient cycles of shallow embayments. In: Cronin, L. E. (ed.) Estuarine research, Vol. I, Chemistry, biology, and the estuarine system. Academic Press, New York, p. 563-579

Riley, G. A. (1941). Plankton studies. IV. Georges Bank. Bull. Bingham Oceanogr. Coll. $7(4): 1-73$

Roman, M. R. (1978). Tidal resuspension in Buzzards Bay, Massachusetts. II. Seasonal changes in the size distribution of chlorophyll, particulate concentration, carbon and nitrogen in resuspended particulate matter. Estuar. coast. mar. Sci. 6: $47-53$

Ryther, J. H., Dunstan, W. M. (1971). Nitrogen, phosphorus, and eutrophication in the coastal marine environment. Science 171: 1008-1013

Smayda, T J. (1983). The phytoplankton of estuaries. In: Ketchum, B. H. (ed.) Estuaries and enclosed seas. Elsevier, Amsterdam, p. 65-102

Smayda, T. J. (1984). Variations and long-term changes in Narragansett Bay, a phytoplankton-based coastal marine

This article was presented by $R$. Williams, Plymouth, UK ecosystem: relevance to field monitoring for pollution assessment. In: White, H. H. (ed.) Concepts in marine polfution measurements. University of Maryland Sea Grant Publ., College Park, p. 663-679

Smayda, T J. (1990). Novel and nuisance phytoplankton blooms in the sea: evidence for a global epidemic. In: Graneli, E., Sundstrom, B., Edler, L., Anderson, D. M. (eds.) Toxic marine phytoplankton. Elsevier, Amsterdam, p. $29-40$

Sverdrup, H. U. (1953). On conditions for the vernal blooming of phytoplankton. J. Cons, int. Explor. Mer 18: 287-295

Townsend, D. W., Cammen, L. M., Christensen, J. P., Ackleson, S. G., Keller, M. D., Haugen, E. M., Corwin, S., Bellows, W. K., Brown, J. F. (1991). Seasonality of oceanographic conditions in Massachusetts Bay. Final report to Massachusetts Water Resources Authority, Bigelow Laboratory for Ocean Sciences Technical Report No. 83, Boothbay Harbor, ME

Turner, J. T., Borkman, D. G. (1993). Plankton studies in Buzzards Bay, Massachusetts, USA. I. Hydrography and bacterioplankton, 1987 to 1990. Mar. Ecol. Prog. Ser. 100: $17-26$

Turner, J. T., Bruno, S. F., Larson, R. J., Staker, R. D., Sharma, G. M. (1983). Seasonality of plankton assemblages in a temperate estuary. P.S.Z.N. I: Mar. Ecol. 4: 81-99

Manuscript first received: October 26, 1992

Revised version accepted: June 14, 1993 